\title{
PELATIHAN MENDESAIN MEDIA PEMBELAJARAN MENGGUNAKAN MODEL DICK AND CAREY BAGI GURU-GURU DI KECAMATAN PENEBEL
}

\author{
oleh, \\ Ni Nyoman Parwati dan I Nengah Suparta \\ Jurusan Pendidikan Matematika \\ Fakultas Matematikan dan Ilmu Pengetahuan Alam \\ Universitas Pendidikan Ganesha
}

\begin{abstract}
ABSTRAK
Tujuan dari kegiatan Pengabdian pada Masyarakat (P2M) ini adalah Meningkatkan pengetahuan dan keterampilan para guru dalam mendesain media pembelajaran menggunakan model Dick \& Carey di Kecamatan Penebel. Kegiatan P2M ini melibatkan 20 orang guru SD dan Kepala sekolah di Kecamatan Penebel yang dilaksanakan dalam bentuk pelatihan. Pelaksanaan kegiatannya, sebagai berikut: (1) Melaksanakan pelatihan desain media pembelajaran selama dua hari, meliputi: hari pertama pelatihan secara teoritis tentang desain media pembelajaran; hari kedua, pelatihan merancang beberapa contoh media pembelajaran yang akan dikembangkan. (2) Membimbing guru dalam mengembangkan media pembelajaran menggunakan model Dick \& Carey selama dua bulan. (3) Melakukan penilaian terhadap media pembelajaran yang dihasilkan oleh para guru. Hasil yang diperoleh dari seluruh kegiatan P2M ini adalah draf media pembelajaran sebanyak 6 jenis untuk mata pelajaran matematika SD dengan kualitas "baik", yaitu: luas daerah trapesium 3 set, luas daerah jajar genjang 3 set, luas daerah layang-layang 3 set, luas daerah belah ketupat 3 set, luas daerah segitiga 3 set, dan alat peraga blok pecahan 2 set. Tanggapan guru-guru terhadap pelaksanaan kegiatan $\mathrm{P} 2 \mathrm{M}$ ini adalah "sangat positif". Usulan program lanjutan yang diajukan terkait dengan pelaksanaan kegiatan P2M ini adalah pendampingan pelaksanaan pembelajaran berbantuan media eksploratif bagi guru-guru SD di Kecamatan Penebel. Hal ini dilakukan sebagai kegiatan lanjutan dari pengembangan draf bahan ajar yang telah dihasilkan pada kegiatan P2M ini.
\end{abstract}

Kata-kata kunci: media pembelajaran, desain pengembangan model Dick and Carey

\section{Pendahuluan}

Penjabaran dari UU No. 20 tahun 2003 tentang sistem pendidikan nasional, mendasarkan pada profesionalisme guru, yaitu standar kompetensi yang harus dikuasai seorang pendidik (guru). Dijelaskan, standar kompetensi yang harus dimiliki guru mencakup empat jenis kompetensi yaitu: kompetensi pedagogik, kepribadian, 
profesional, dan sosial. Persyaratan kompetensi guru tersebut dibuktikan dengan sertifikat pendidik yang diperoleh melalui sertifikasi.

Sertifikasi guru dalam jabatan telah berlangsung sejak tahun 2006. Berdasarkan hasil uji sertifikasi guru dalam jabatan yang telah dilakukan di Rayon 21 Universitas Pendidikan Ganesha, diketahui bahwa peserta sertifikasi yang tidak lulus dalam penilaian fortofolio untuk kuota tahun 2011 sekitar 25\% dari peserta sertifikasi (arsip panitia sertifikasi Rayon 21 Undiksha). Selain itu, dari data kelulusan peserta sertifikasi guru untuk tahun-tahun sebelumnya, menunjukkan persentase ketidak lulusan yang lebih besar yaitu sekitar $40 \%$. Melihat besarnya angka ketidaklulusan peserta sertifikasi guru dalam jabatan, tampaknya perlu dikaji secara lebih mendalam tentang faktor-faktor yang menghambat para peserta untuk mencapai kelulusan dalam uji sertifikasi tersebut. Berdasarkan pengalaman sebagai anggota assessor sertifikasi guru dalam jabatan di Rayon 21 Universitas Pendidikan Ganesha, pengetahuan dan pengalaman para guru untuk melakukan pengembangan perangkat pembelajaran masih sangat kurang.

Melihat kenyataan yang diuraikan di atas, tampaknya perlu dilakukan suatu kegiatan yang mampu meningkatkan pemahaman dan keterampilan para guru dalam mengembangkan profesionalisme, khususnya dalam pendesainan/ pengembangan media pembelajaran. Media pembelajaran yang dimaksud adalah sesuatu (bisa alat, bahan, atau keadaan) yang digunakan sebagai perantara komunikasi dalam kegiatan pembelajaran. Ada enam kategori dasar tentang media, yaitu: teks, audio, visual, video, manipulatif (objek-objek), dan orang (Januszewski, dkk., 2008; Smaldino, dkk., 2008). Dalam hal ini dilakukan kegiatan pengabdian pada masyarakat (P2M) sebagai salah satu kegiatan Tri Dharma Perguruan Tinggi yang mutlak dilakukan oleh dosen. Kegiatan P2M ini dilakukan di Kecamatan Penebel. Khalayak yang menjadi sasaran kegiatan ini adalah para guru SD di Kecamatan Penebel, yang diambil secara acak. Kegiatan ini berupa pelatihan dengan menekankan pada penguasaan terhadap teori dan praktek desain media pembelajaran. Terdapat beberapa model pengembangan desain pembelajaran secara sistematis yang terkenal, seperti: Model Kemp, Assure, dan Dick \& Carey. Model Dick \& Carey adalah yang paling banyak digunakan oleh desainer pembelajaran dan pelatihan. Proses pengembangan menurut Dick \& Carey (2001) meliputi 10 tahap, yaitu: (1) Menganalisis kebutuhan untuk mengidentifikasi tujuan (instructional goal); (2) Menganalisis pembelajaran; (3) Menganalisis pebelajar dan konteksnya; (4) 
Menuliskan tujuan unjuk kerja; (5) Mengembangkan instrumen penilaian; (6) Mengembangkan strategi pembelajaran; (7) Mengembangkan dan memilih bahan pembelajaran; (8) Merancang dan melaksanakan Evaluasi formatif; (9) Merevisi pembelajaran; dan (10) Merancang dan melaksanakan evaluasi sumatif.

Langkah awal pelaksanaan kegiatan ini adalah melakukan analisis situasi. Lokasi Kecamatan Penebel Kabupaten Tabanan, sekitar 80 km dari kota Singaraja, dengan medan yang cukup berat. Banyak sekolah yang ada di Kecamatan Penebel, yaitu: SD sebanyak 34 sekolah, SMP sebanyak 3 sekolah, dan SMA satu sekolah. Lokasi sekolah dasar khususnya, sebagian besar terletak di daerah pedesaan sehingga kegiatan P2M di bidang pendidikan yang dilakukan oleh Universitas Pendidikan Ganesha sangat jarang sampai ke wilayah-wilayah tersebut. Lokasi-lokasi sekolah yang sebagian besar terletak pada daerah yang agak terpencil mengakibatkan para guru jarang terlibat dalam kegiatan-kegiatan ilmiah yang dilakukan oleh Perguruan Tinggi. Sebagai dampaknya pengetahuan dan pemahaman para guru di wilayah ini masih kurang terkait dengan desain pembelajaran ataupun inovasi-inovasi kegiatan pembelajaran lainnya. Informasi yang sama, juga diperoleh dari hasil wawancara yang dilakukan dengan beberapa guru SD, SMP, dan SMA yang ada di Penebel.

Mempertimbangkan jumlah guru yang cukup banyak, dengan pemahaman yang masih kurang dalam desain pembelajaran, maka dipandang perlu untuk mengadakan kegiatan P2M yang melibatkan para guru di daerah ini. Kegiatan ini dimaksudkan untuk memotivasi para guru dan siswa di sekolah tersebut agar mau melaksanakan kegiatan belajar dan mengajar secara lebih efektif dan inovatif. Di samping itu, agar para guru khususnya dalam mengajar mau melakukan inovasi-inovasi sebagai bagian dari tugas profesionalismenya. Media pembelajaran yang dikembangkan ini, diharapkan mampu memfasilitasi siswa untuk belajar dengan lebih mudah sehingga proses dan hasil belajar dapat dicapai dengan lebih berkualitas. Mitra dari kegiatan P2M ini adalah guruguru SD di Kecamatan Penebel. Guru-guru yang terlibat diambil dari tiga gugus di kecamatan Penebel sebanyak 20 orang.

Beberapa masalah yang berhasil diidentifikasi yang terjadi pada sebagian besar sekolah di kecamatan Penebel adalah sebagai berikut. (1) Pengetahuan dan keterampilan para guru tentang prosedur pengembangan media pembelajaran masih sangat kurang. (2) Pelibatan para guru dalam kegiatan ilmiah masih kurang. (3) Kinerja para guru 
dalam membuat media pembelajaran, masih kurang. Berdasarkan hal ini secara umum masalah yang dapat dirumuskan adalah "Perlunya meningkatkan pengetahuan dan keterampilan para guru dalam mendesain media pembelajaran di kecamatan Penebel"

\section{Metode Pelaksanaan Pengabdian}

Berdasarkan masalah yang dialami oleh para guru di lokasi P2M yang dilaksanakan ini, maka hal yang dilakukan untuk memecahkan masalah tersebut adalah dengan memberikan kegiatan pelatihan. Pelatihan yang diberikan adalah menyangkut mendesain media pembelajaran menggunakan model Dick \& Carey. Pelatihan secara teoritis, dilakukan selama dua hari dan kegiatan praktek mendesain media pembelajaran dilakukan secara mandiri selama dua bulan. Dengan demikian para guru mendapat pemahaman secara menyeluruh tidak sekadar pemahaman secara teoritis saja.

Kegiatan pelatihan selama 2 hari dilaksanakan di SD 1 Penebel pada tanggal 24-25 Agustus 2012. Pemilihan lokasi ini didasarkan pada kemudahan atau sangat strategis bagi peserta dari masing-masing SD di kebendesaan untuk menjangkau lokasi ini. Pemanfaatan lokasi ini didasarkan atas ijin kepala sekolah dan dinas pendidikan kecamatan Penebel. Praktek penyusunan media selanjutnya, dilakukan dalam bentuk kegiatan kerja mandiri dan dilakukan monitoring oleh tim pelaksana kegiatan P2M yang dibantu oleh 4 orang kepala sekolah, yaitu kepala sekolah SD 1 dan SD 2 Penebel, kepala SD 2 Pitera, dan kepala SD 1 Babahan. Kerja mandiri dilakukan pada bulan September sampai Oktober 2012, yaitu merancang media pembelajaran sesuai dengan konsep-konsep esensial yang dipilih guru. Mulai minggu ketiga bulan Oktober, dilakukan penilaian terhadap produk media yang telah dihasilkan oleh guru.

Aktivitas P2M ini meliputi tiga jenis kegiatan, yaitu: (1) Melaksanakan pelatihan desain media pembelajaran selama dua hari, meliputi: hari pertama pelatihan secara teoritis tentang desain media pembelajaran; hari kedua, pelatihan merancang beberapa contoh media pembelajaran yang akan dikembangkan. (2) Membimbing guru dalam mengembangkan media pembelajaran menggunakan model Dick \& Carey selama dua bulan. (3) Melakukan penilaian terhadap media pembelajaran yang dihasilkan oleh para guru.

Evaluasi keberhasilan kegiatan ini dilihat dari kualitas media pembelajaran yang dihasilkan oleh para guru mitra. Kualitas media pembelajaran yang dihasilkan dilihat 
dari beberapa aspek, yaitu: (a) kompetensi, indikator, perangkat dan media yang sesuai, (b) langkah-langkah penggunaan media pembelajaran, (c) evaluasi dan asesmen pembelajaran, (d) manfaat media pembelajaran, dan (e) bentuk fisik (Parwati, dkk., 2007; 2008).

Setelah kegiatan pelatihan selesai, para peserta diberikan angket terkait dengan tanggapan mereka terhadap pelatihan yang diberikan. Angket tanggapan guru (peserta) meliputi beberapa aspek, yaitu: manfaat kegiatan pelatihan dalam menunjang tugas profesi guru, menambah wawasan guru tentang prosedur pengembangan media pembelajaran yang eksploratif, meningkatkan pengetahuan tentang teknik pembuatan media pembelajaran eksploratif, memotivasi guru untuk menggunakan media dalam melaksanakan pembelajaran, dan perlunya diadakan program P2M lanjutan yang serupa (Parwati, dkk., 2007; 2008). Analisis data dilakukan secara deskriptif.

\section{Hasil dan Pembahasan}

Kegiatan P2M ini terlaksana sesuai dengan rencana dan jadwal yang telah ditetapkan. Pelatihan dilaksanakan selama dua hari. Kegiatan hari pertama adalah memberikan penjelasan/informasi/wawasan mengenai hakikat media pembel-ajaran dilanjutkan dengan kegiatan diskusi. Kegiatan hari kedua adalah pelatihan merancang beberapa contoh media media pembelajaran dan simulasi pelaksanaan pembelajaran menggunakan bantuan media eksploratif. Merancang media pembelajaran yang eksploratif sesuai dengan konsep-konsep materi esensial dilakukan selama dua bulan dalam bentuk kegiatan pendampingan di sekolah masing-masing. Dari kegiatan tersebut, telah berhasil disusun media pembelajaran, namun masih terbatas untuk materi matematika SD. Media pembelajaran yang telah berhasil dirancang sebanyak 6 jenis draf media pembelajaran matematika SD, yaitu: luas daerah trapesium 3 set, luas daerah jajar genjang 3 set, luas daerah layang-layang 3 set, luas daerah belah ketupat 3 set, luas daerah segitiga 3 set, dan alat peraga blok pecahan 2 set. Media pembelajaran yang dihasilkan dibuat dari kertas buffalo dan dileminating, sehingga bisa digunakan secara berulang-ulang dan dalam jangka waktu yang relatif lama. Guru yang dilibatkan dalam merancang media pembelajaran ini, sebanyak 17 orang. Berdasarkan pedoman evaluasi yang telah ditetapkan, nilai rata-rata media pembelajaran yang telah dihasilkan, sebesar 83 yang berada dalam kualifikasi "baik". Tanggapan guru dan kepala sekolah 
terhadap kegiatan P2M yang dilaksanakan rata-rata sebesar 86 tergolong "sangat positif".

Pengembangan media pembelajaran agar menghasilkan produk yang efektif dan layak pakai, menurut desain pembelajaran model Dick and Carey, setelah dilakukan penyusunan draf perlu dilanjutkan dengan tahap uji coba. Pelaksanaan uji coba harus dilakukan secara bertahap pula. Pada kegiatan P2M ini, hanya bisa dilakukan sampai pada tahap penyusunan draf media pembelajaran, karena keterbatasan waktu, tenaga, dan anggaran yang dimiliki. Oleh karena itu, sangat diperlukan kegiatan lanjutan agar dapat dihasilkan media pembelajaran yang efektif, efisien, dan memiliki daya tarik (Reigeluth, 1999), sehingga dapat digunakan dalam melaksanakan kegiatan pembelajaran di kelas oleh para guru. Dengan demikian pelaksanaan pembelajaran akan berlangsung dengan lebih bermakna dan hasil belajar siswa semakin meningkat.

Faktor pendukung dari pelaksanaan kegiatan P2M ini adalah antusias para peserta (guru mitra) untuk mengikuti kegiatan. Semua peserta pelatihan berperan serta secara aktif dalam kegiatan pelatihan dan memberikan tanggapan yang sangat positif terhadap pelaksanaan kegiatan ini. Keterlibatan para guru dalam kegiatan P2M ini memegang peranan untuk menentukan keberhasilan dari pelaksanaan kegiatan ini. Hal ini karena sasaran dari kegiatan ini adalah peningkatan pemahaman dan kemampuan para guru dalam mengembangkan media pembelajaran dengan kualitas valid dan layak pakai.

Kegiatan P2M ini telah berlangsung sesuai dengan rencana dan tujuan yang telah ditetapkan. Hal ini terlihat dari kualitas draf media pembelajaran yang telah dihasilkan oleh para guru berada dalam kualifikasi "baik". Draf media pembelajaran yang telah dihasilkan, perlu diujicoba untuk mendapatkan produk yang dapat digunakan pada kelas yang sesungguhnya. Kegiatan ini baru bisa melibatkan peserta sebanyak 17 orang guru dan 3 kepala sekolah di kecamatan Penebel. Mempertimbangkan jumlah guru yang cukup banyak di kecamatan Penebel dengan kemampuan dalam desain pembelajaran rata-rata masih kurang, maka dipandang perlu untuk mengadakan kegiatan lanjutan dengan melibatkan guru-guru di gugus yang lain. Kegiatan ini juga mendapat tanggapan sangat positif dari Kepala Sekolah, Kepala UPP Kecamatan, dan guru-guru lain di Kecamatan Penebel.

Sekalipun pelaksanaan kegiatan P2M ini berjalan lancar, namun ada kendala sebagai faktor penghambat dari pelaksanaan P2M ini adalah waktu pelaksanaannya 
sangat singkat sehingga draft media pembelajaran yang dihasilkan hanya untuk beberapa pokok bahasan dan belum bisa melakukan tahap pengembangan media pembelajaran sampai menghasilkan media pembelajaran yang valid dan layak pakai. Kendala tersebut dapat dijadikan sebagai bahan refleksi, pertimbangan, dan saran untuk mengadakan kegiatan P2M lanjutan.

\section{Penutup}

Berdasarkan hasil yang diperoleh dalam pelaksanaan kegiatan P2M ini, dapat disimpulkan bahwa kegiatan P2M dapat terlaksana dengan baik. Telah berhasil diranang 6 jenis draf media pembelajaran matematika dengan kualifikasi baik. Kegiatan P2M ini mendapat tanggapan sangat positif dari kalangan guru dan kepala sekolah di Kecamatan Penebel. Saran yang dapat diajukan untuk kegiatan lanjutan terkait dengan pelaksanaan P2M ini adalah guru-guru peserta kegiatan P2M agar dapat melanjutkan pengembangan media pembelajaran terutama pada pokok bahasan yang lain atau mata pelajaran lain yang belum diselesaikan saat kegiatan P2M ini berlangsung. Kegiatan P2M ini perlu dilanjutkan berupa pendampingan pengembangan media pembelajaran bagi guru-guru SD di Kecamatan Penebel sebagai penyempurnaan dari draf media pembelajaran yang telah dihasilkan dalam kegiatan ini.

\section{DAFTAR PUSTAKA}

Dick, W., Carey, L., \& Carey, J. O. 2001. The Systematic Design Of Instruction. USA: Addison-Wesley Educational Publisher Inc.

Januszewski, A., Molenda, M. 2008. Educational Technology. New York: Lawrence Erlbaum Associates.

Parwati, N.N., Mariawan, I. M., \& Suarsana, I. M. 2007. Peningkatan Profesionalisme Guru Matematika Melalui Pelatihan Implementasi Model-model Pembelajaran Berbantuan Alat Peraga Bagi Guru-Guru Sekolah Dasar No 3 Mengesta. Laporan P2M. Tidak diterbitkan. Singaraja: Undiksha.

Parwati, N.N. \& Mariawan, I. M. 2008. Pelatihan Penelitian Tindakan Kelas untuk Guru-guru SD di Kabupaten Tabanan. Laporan P2M. Tidak diterbitkan. Singaraja: Undiksha. 
Reigeluth, C. M. 1999. Instructioanl-design theories and models: A new paradigm of instructional theory. Volume II. New Jersey: Lawrence Erlbaum Associates, Publishers.

Smaldino, S.E. , Lowther, D.L. \& Russell, J.D. 2008. Instructional Media and Technology for Learning. $9^{\text {th }}$ Edition. Upper Saddle Rive NJ: Pearson Education, Inc.

Undang-undang RI Nomor 20 tahun 2003 tentang Sisem Pendidikan Nasional. 2003. (Online) tersedia dalam www.hukumonline.com. 